\title{
Global Policy Overview of Groundwater in Urban Development-A Tale of 10 Cities!
}

\author{
Stephen Foster 1,2,3 \\ 1 Groundwater Management Specialist Group, International Water Association, \\ 2521 Den Haag, The Netherlands; DrStephenFoster@aol.com \\ 2 Urban Groundwater Network, International Association of Hydrogeologists, P.O. Box 4130, Goring, \\ Reading RG8 6BJ, UK \\ 3 Department of Earht Sciences, University College London, London WC1E 6BT, UK
}

Received: 18 December 2019; Accepted: 4 February 2020; Published: 8 February 2020

\begin{abstract}
Urbanisation is the predominant global phenomenon of our time. This overview provides an assessment of the trends in both public and private use of groundwater for urban water-supply in 10 developing cities and their policy implications, which is based on the global experience during 2001-2012 of the World Bank-Groundwater Management Advisory Team (a multi-disciplinary team of groundwater specialists working long-term for the World Bank, with special funding principally from the Netherlands Government supplemented by the United Kingdom and Denmark), together with subsequent follow-up enquiries. The strategic assessment analyses both the benefits to water users and the broader community of groundwater use, and the associated risks in terms of (a) compromising resource sustainability, (b) impacting the built infrastructure, (c) public-health hazards arising from widespread groundwater pollution and (d) the economic distortion of water-sector investments.
\end{abstract}

Keywords: urban development; developing cities; groundwater policy; integrated management

\section{Objective of This Overview}

In the course of providing data analysis and investment advice to potential World Bank-funded urban water-supply and water-resource projects worldwide, the World Bank-Groundwater Management Advisory Team (GW-MATe) collected extensive evidence of fast-increasing dependence upon groundwater (for public and/or private water-supply) with both benefits and hazards to water users and the broader community, in the 10 developing cities that are the focus of this paper (Table 1). The detailed results of the GW-MATe technical surveys and policy diagnostics are available elsewhere [1,2] and thus the primary objective of the present paper is to provide a concise global overview of the results of that work, without entering into detail about each of the 10 cities nor about the methodologies employed.

Table 1. Summary of groundwater concerns and management approaches in 10 cities assessed.

\begin{tabular}{cccc}
\hline CITY Country & $\begin{array}{c}\text { POPULATION * } \\
\text { Utility Water-Supply }\end{array}$ & $\begin{array}{c}\text { MAIN ISSUES AND } \\
\text { CONCERNS }\end{array}$ & MANAGEMENT APPROACH \\
\hline BANGKOK Thailand [3] & $\begin{array}{c}\text { Municipal groundwater use } \\
(5 \%-10 \% \text { groundwater })\end{array}$ & $\begin{array}{c}\text { Water utility groundwater use } \\
\text { constrained but massive private } \\
\text { waterwell construction into the } \\
1990 \text { s, causing land subsidence } \\
\text { and other impacts }\end{array}$ & $\begin{array}{c}\text { drastically reduced; groundwater } \\
\text { resource regulator empowered to } \\
\text { control private waterwell use }\end{array}$ \\
\hline
\end{tabular}


Table 1. Cont.

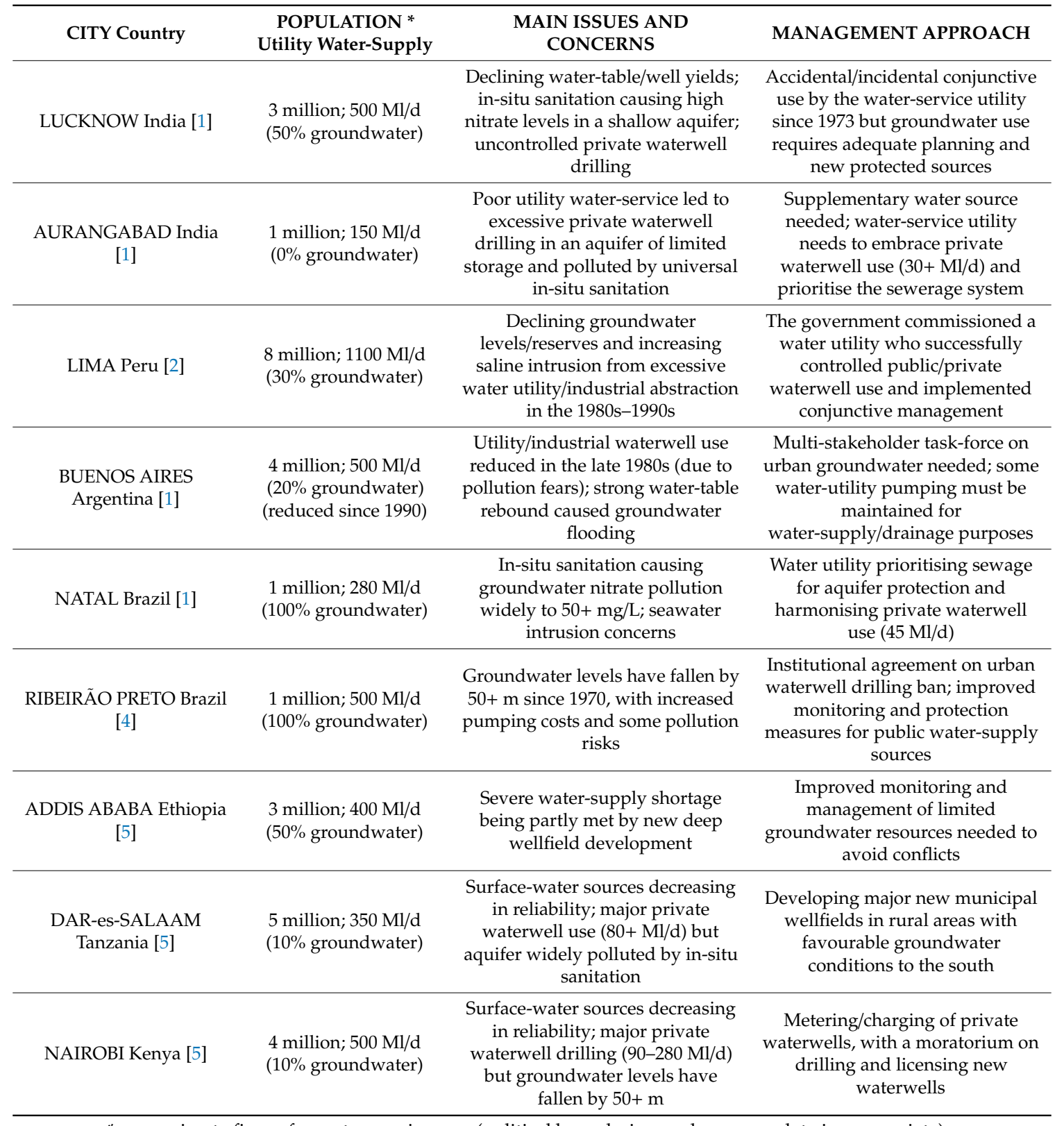

* approximate figure for water-service area (political boundaries render census data inappropriate).

\section{Context for Policy Development}

\subsection{Drivers of Urban Groundwater}

Dependence on groundwater for public and/or private water-supply is a fast-increasing phenomenon in developing cities [6-9], which is occurring in response to population growth, accelerating urbanisation, higher ambient temperatures, increasing per capita usage and reduced security of river intakes (due to increased pollution). This global trend has been facilitated by the reducing (and generally modest) cost of waterwell construction [10]. Today many cities-from across the EU and USA to Brazil, China, India, Mexico, Nigeria, Pakistan and Vietnam-exhibit a high level of dependence on groundwater for urban water-supply. 


\subsection{Major Issues Relating to Increased Groundwater Use}

Those urban centres underlain and/or surrounded by high-yielding aquifers (e.g., Bangkok, Lima, Lucknow, Natal and Ribeirão Preto/Table 1) usually have better public water-service levels. However, there are rarely sufficient groundwater resources within urban areas themselves to satisfy the entire water demand of larger cities, and resource sustainability often becomes an issue with serious localised aquifer depletion, potentially causing quasi-irreversible side-effects (such as induced seepage of contaminated water, land subsidence and coastal saline intrusion) [1,11].

This situation is often exacerbated by groundwater quality deterioration due to inadequately controlled urban sanitation, given the close connection of wastewater handling, disposal and re-use with underlying shallow groundwater (e.g., Lucknow and Natal/Table 1). It is thus critical that groundwater quality is systematically monitored, and the risks posed by pollution carefully assessed and acted upon [10].

The use of groundwater is not restricted to cities with ready access to high-yielding aquifers, but also occurs widely where the public water-supply is imported from distant surface-water sources of low reliability and high cost (e.g., Aurangabad, Dar-es-Salaam and Nairobi/Table 1). In this situation, private in-situ waterwell construction often mushrooms, and self-supply from groundwater widely represents a significant proportion of water 'actually received' by users (widely $20 \%-30 \%$ of total water-supply and well above $50 \%$ in extreme cases).

\section{Urban Interactions with Groundwater}

Urbanisation modifies the groundwater flow and quality regime in underlying shallow aquifers by:

- substantially increasing recharge rates-since the reduction of infiltrating rainfall through land-surface impermeabilisation almost always is more than compensated for by water-mains leakage, infiltrating pluvial drainage and the incidental 'return' of wastewater from in-situ sanitation and sewer leakage, especially where the municipal water-supply is 'imported from external sources'.

- greatly increased subsurface contaminant load, mainly from in-situ sanitation (in developing cities), and to lesser degree from sewer leakage and casual spillage/disposal of industrial and community chemicals.

These modifications are in continuous evolution. The processes combine to present numerous threats and some benefits for urban groundwater resources [8] — with the threats being more severe where shallow aquifers are used for private in-situ self-supply. In one sense, groundwater systems under cities represent 'the ultimate sink' for urban pollutants (with nitrates from wastewater and some synthetic hydrocarbons being very persistent), but in practice the extent to which the contaminant load impacts groundwater will vary widely with the vulnerability of the aquifer system.

In turn, man-made modifications to groundwater regimes can seriously impact urban infrastructure, with the impacts becoming more serious under unstable groundwater conditions:

- falling water-table due to excessive groundwater extraction, leading to land subsidence, building damage and increased surface-water flood risk (e.g., Bangkok/Table 1);

- water-table rebound, if groundwater use is abandoned for some reason such as serious pollution (e.g., Buenos Aires/Table 1), causing basement damage, groundwater flooding to transportation routes, malfunction of septic tanks and excessive inflows to deep collector sewers.

All of these problems can be very costly and surprisingly persistent-and while most are 'predictable' in theory, they are rarely 'predicted' in practice because of the widespread absence of an institution charged with the oversight and management of urban groundwater. 


\section{Integrating Groundwater into Urban Water and Land Management}

Groundwater is far more significant in the water-supply of fast-developing cities than is widely appreciated, and is also the 'invisible link' between various facets of the urban infrastructure. Regretfully, many organisations concerned with urban water-supply and environmental management have a poor understanding of groundwater as a component of the urban water-cycle and one that always needs to be integrated into decisions on urban infrastructure planning and investment, whatever its status.

\subsection{Conserving Groundwater Reserves for Water-Supply Security}

In future, it will be important for the major groundwater storage of most aquifers to be used to improve urban water-supply security, as part of a strategy to cope with the pressures generated by urban growth and climate change.

First and foremost, there is widely a need to introduce effective demand management measures to constrain unnecessary use and to reduce 'unaccounted for water', and these need to be accompanied by managed aquifer recharge (from roof-drainage soakaways, permeable pavements and injection of excess surface water via lagoons or large wells) to maximise urban aquifer replenishment. All of this will require a 'resource culture' to be cultivated within water utilities.

Where existing groundwater development is excessive and beginning to cause land subsidence that may threaten the stability of urban infrastructure, there is a need to employ risk assessment techniques to identify potential problems [12,13].

It is important that schemes of conjunctive use of groundwater and surface-water sources (Figure 1) be pursued imaginatively, since most so-called 'conjunctive use' currently practised in developing cities amounts to a 'piecemeal coping strategy' rather than the more 'optimised approaches' that have been successfully implemented in Lima and Bangkok (Table 1).
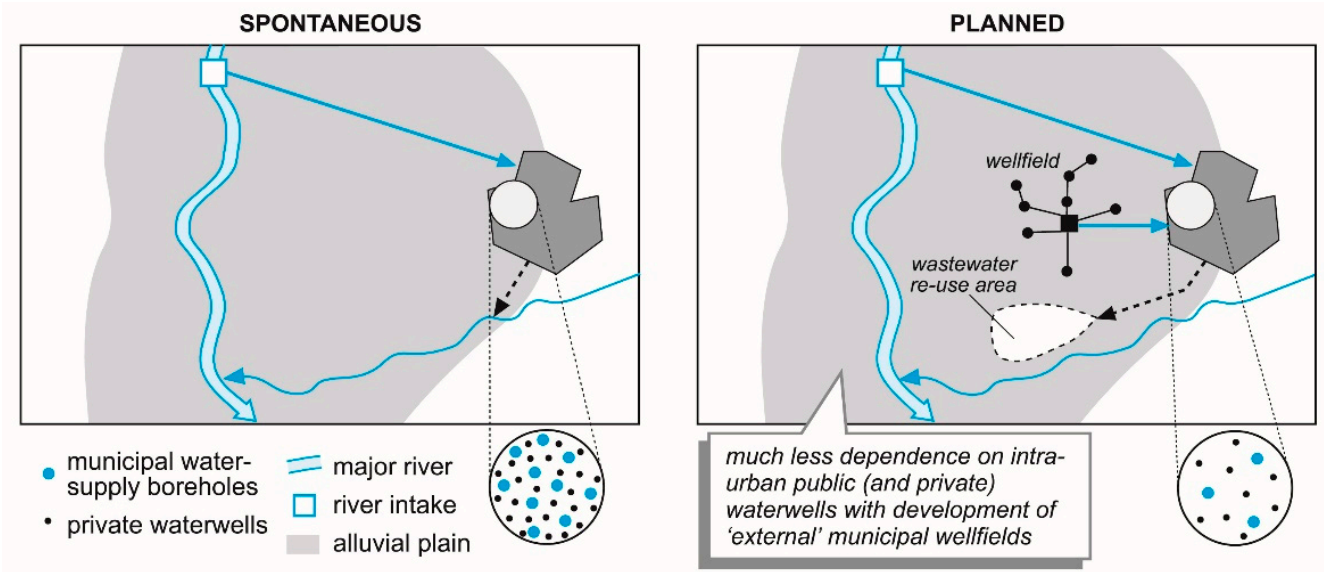

Figure 1. Planned and spontaneous conjunctive use for urban water-supply.

The development of external wellfields for utility water-supply (e.g., Addis Ababa, Dar-es-Salaam and Ribeirão Preto/Table 1) is another much needed policy response for the strategic use of groundwater. Investment in such wellfields and water delivery-mains requires insurance through declaring their 'capture areas' as drinking-water protection zones [14,15]. This often encounters administrative impediments related to fragmented powers between the municipalities comprising 'metropolitan areas', and improved governance arrangements and economic incentives need to be explored to overcome this problem.

Given the continuous evolution of groundwater use in 'urban aquifers', and some hydrogeologic uncertainty in predicting their precise behaviour, it is desirable to adopt an 'adaptive management approach' to urban groundwater resources. This should be based on continuous monitoring of groundwater levels and quality, and guided by a (periodically updated) numerical aquifer model. 


\subsection{Incorporating Groundwater into Sanitation and Drainage Planning}

The groundwater-sanitation nexus is extremely relevant in developing nations, where extensive in-situ sanitation presents a significant groundwater quality hazard (Figure 2). It may be decades before the full extent of pollution becomes fully apparent because contamination of large aquifers is a gradual and insidious process. Thus, it is critically important to recognise the incipient signs of groundwater pollution through shallow aquifer monitoring and to put in place groundwater protection measures.

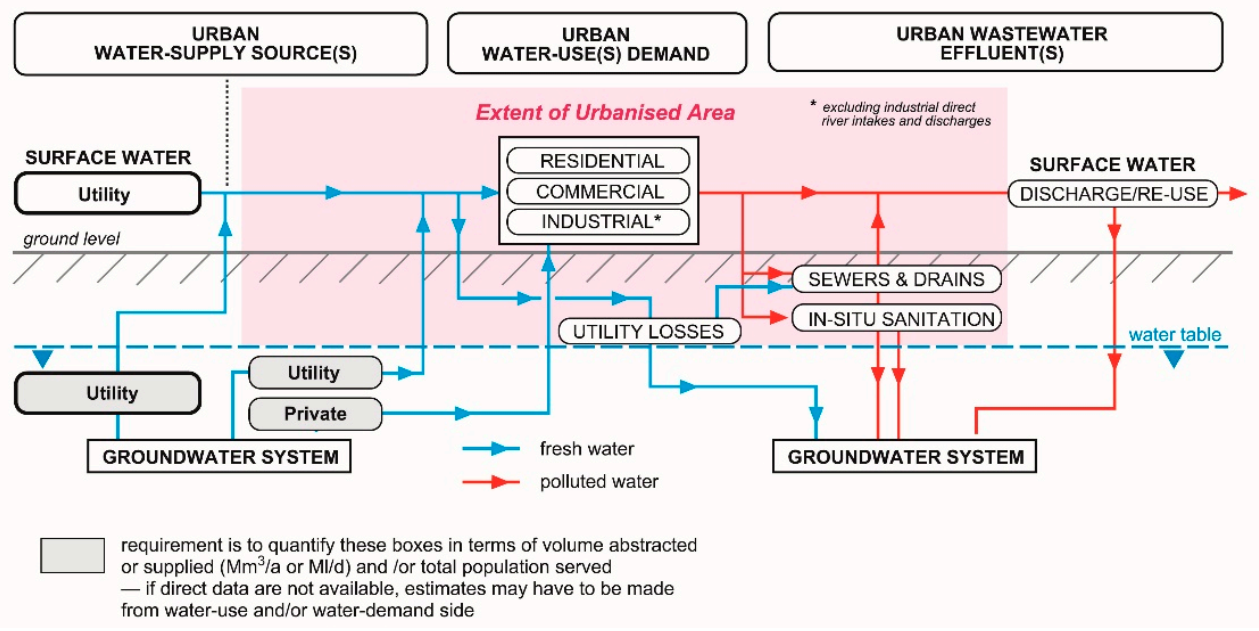

Figure 2. Groundwater relations within the urban water-cycle.

In most settings (except for shallow and vulnerable aquifers), there will be sufficient attenuation capacity to eliminate faecal pathogens from percolating wastewater, but the hazard increases markedly with inadequate waterwell construction and/or poor septage management, which are typical of anarchical fast-growing cities. However, troublesome levels of nitrogen compounds and dissolved organic carbon will arise to varying degrees, depending on the population density served by in-situ sanitation. For municipal water-supply, the problem is often dealt with by dilution through mixing, but this requires a secure source of high-quality water and also has absolute limitations because some wastewaters contain a wide array of pharmaceutical residues and industrial chemicals.

An integrated approach is required to reduce the cost and improve the security of the urban water infrastructure. There are numerous practical measures that can be taken to improve the sustainability of groundwater use, including:

- $\quad$ prioritisation of recently-urbanised districts for sewerage cover to protect their good-quality groundwater from gradual degradation;

- $\quad$ establishment of groundwater protection zones around utility waterwells favourably located to take advantage of parkland;

- $\quad$ imposition of better controls for the handling and disposal of industrial effluents and solid wastes to reduce the risk of aquifer pollution.

Groundwater pollution can be reduced by deploying dry (eco-sanitation) units, in which urine is separated from faeces, with both being recycled. The latter installations are recommended for new urban areas overlying shallow aquifers, but they are not the universal solution to groundwater contamination because large-scale retro-installation in existing dwellings is very costly.

An important corollary is making better use of increasing wastewater resources generated by wider sewer coverage-this could be through reuse for amenity and agricultural irrigation that is spatially planned and appropriately controlled so as to minimise public health hazards, including incidental pollution of groundwater in potable use [16]. 


\subsection{Private In-Situ Groundwater Use-Reducing Risks and Improving Benefits}

Private capital investment to access groundwater in situ for urban self-supply often mushrooms during periods of inadequate utility water-supply $[1,17]$. This is essentially a 'coping strategy' by multi-residential properties, and commercial and industrial enterprises. Water users tend to take their supply from multiple sources according to their availability and relative cost, with much more expensive tankered water as the last resort.

Private self-supply from groundwater is then likely to continue by many users as a 'cost-reduction strategy' when the availability of the utility supply improves. Although the 'economy of scale' can be poor, the cost of water-supply from this type of source often compares favourably with the tariffs implied by full cost-recovery for new utility surface water-supply schemes. Whether private residential groundwater use presents a serious threat to users will depend on the type of anthropogenic pollution (or natural contamination) present and the type of water-use concerned.

An emerging policy question is under what circumstances the risks or inconveniences of private residential self-supply from urban groundwater justify attempts to ban the practice. Many private waterwells are, at best, unregulated and at worst illegal. In the longer run, this is counterproductive for the private user and the public administration but can be regularised by management interventions such as:

- using advances in geographical positioning and data capture to locate waterwells;

- registering commercial/industrial users and residential use for apartment blocks/housing estates, and charging for groundwater use by waterwell pump capacity or metering discharges to sewers;

- issuing water-quality use advice and health warnings to private waterwell operators, and if pollution is severe, declaring sources unsuitable for potable use;

- gaining civil-society commitment through effective participatory mechanisms and incentives for 'self-monitoring'.

\subsection{Groundwater in Decentralised Urban Water-Service Provision}

Given the escalating rates of urbanisation globally, new paradigms for water-service provision need to be found. 'Closed-loop' operations for suburbs of 10,000-50,000 population on a 'decentralised basis' would appear to be an attractive alternative, either managed by the water utility or a community organisation. Such systems can be operated to minimise infrastructure costs, energy use and water losses, since they reduce the distance between household use and water treatment [18]. They can also promote energy and nutrient recovery by converting the current liability of wastewater treatment into assets, through urine/faeces separation and re-use of the former as a fertiliser and the latter for energy generation.

The natural drought resilience and quality protection of deep waterwells means that they are well suited to be the water-supply source for decentralised closed-loop water-service systems. Since these systems treat wastewater as a resource, their installation should substantially reduce the urban subsurface contaminant load, and thus one major groundwater pollution threat. Nevertheless, it will also be necessary to put more local attention and effort into on-the-ground inspection and control of other forms of urban land and groundwater contamination (such as gasoline stations, small-scale motor shops, dry-cleaning laundries, etc.) to prevent the pollution and loss of key waterwell sources.

\section{Filling the 'Institutional Vacuum' in Urban Groundwater}

There is a clear need for groundwater considerations to be integrated into decision-making on infrastructure planning and investment, but institutional capacity to take the lead is often limited because:

- water-resource agencies rarely have the capacity to cope with urban development dynamics;

- urban water utilities are often 'resource illiterate' despite increasing groundwater dependence; 
- urban land and environment departments have a poor understanding of groundwater.

As a consequence, the strategic importance of urban groundwater is not yet reflected by sufficient investment in management and protection of the resource base. Urban groundwater tends to affect everybody but is often the responsibility of 'no body'. Municipal, provincial or state, and national governments need to find the political will and practical means to:

- constrain groundwater demand and limit abstraction by socio-economic and regulatory measures, so as to avoid excessive aquifer depletion and degradation;

- $\quad$ encourage the spread of groundwater abstraction for municipal water-supply over larger land areas, through the declaration of special conservation and/or protection areas;

- plan urban sanitation better and regulate the storage of industrial chemicals and handling of industrial effluents in the interest of much improved groundwater quality protection.

Governments, from national to local level, need to seek realistic policies and effective institutions to proactively manage urban groundwater resources. They will require political leadership and the engagement of major stakeholder groups. In pursuing these policies, it will be essential to make a critical appraisal of the actual and desirable roles of national/state water-resource and environment agencies, municipal water-service utilities, and municipal government offices responsible for land-use and industrial licenses-as well as the avenues of consultation and communication between them. This is required to address split institutional interests and responsibilities, and identify a mechanism for long-term periodic review and systematic action on urban groundwater.

Moreover, the dynamics of urban development and its relationship with groundwater are such as to merit the formation of a 'cross-sector urban groundwater consortium' (or standing committee) of all major stakeholders and regulatory departments/agencies. Such consortia should be tasked with communicating groundwater issues at the political and executive levels, and must be empowered and financed to define and implement a 'priority action plan'. They must also be provided with a sound technical diagnosis from an appropriate group of institutional and university specialists.

Funding: The writing of this review received no external funding.

Acknowledgments: The author would like to acknowledge stimulating interaction with the following people on urban groundwater issues: Ricardo Hirata (Brazil), Ken Howard (Canada), John Chilton (UK) and Radu Gogo (Romania), and the anonymous reviewers of this paper who made valuable suggestions for its improvement.

Conflicts of Interest: The author declares no conflict of interest.

\section{References}

1. Foster, S.; Hirata, R.; Misra, S.; Garduño, H. Urban Groundwater Use Policy-Balancing the Benefits and Risks in Developing Nations; GW-MATe Strategic Overview Series 3; World Bank: Washington, DC, USA, 2011. Available online: www.un-igrac.org (accessed on 1 September 2019).

2. Foster, S.; van Steenbergen, F.; Zuleta, J.; Garduño, H. Conjunctive Use of Groundwater and Surface Water-From Spontaneous Coping Strategy to Adaptive Resource Management; GW-MATE Strategic Overview Series 2; World Bank: Washington, DC, USA, 2010. Available online: www.un-igrac.org (accessed on 1 September 2019).

3. Buapeng, S.; Foster, S. Controlling Groundwater Abstraction and Related Environmental Degradation in Metropolitan Bangkok, Thailand; GW-MATe Case Profile Collection 20; World Bank: Washington, DC, USA, 2008. Available online: www.un-igrac.org (accessed on 1 September 2019).

4. Foster, S.; Hirata, R.; Vidal, A.; Schmidt, G.; Garduño, H. The Guarani Aquifer Initiative-Towards Realistic Groundwater Management in a Transboundary Context; GW-MATe Case Profile Collection 9; World Bank: Washington, DC, USA, 2009. Available online: www.un-igrac.org (accessed on 1 September 2019).

5. Tuinhof, A.; Foster, S.; van Steenbergen, F.; Talbi, A.; Wishart, M. Appropriate Groundwater Management Policy for Sub-Saharan Africa in Face of Demographic Pressure and Climatic Variability; GW-MATe Strategic Overview Series 5; World Bank: Washington, DC, USA, 2011. 
6. Howard, K.W.F. Urban Groundwater-Meeting the Challenge; IAH Selected Paper Series 8; Taylor \& Francis: Oxford, UK, 2007.

7. Taniguchi, M.; Dausman, A.; Howard, K.; Polemio, M.; Lakshmana, T. Trends and sustainability of groundwater in highly stressed aquifers. In Proceedings of the Symposium HS. 2 at the Joint Convention of the International Association of Hydrological Sciences (IAHS) and the International Association of Hydrogeologists (IAH), Hyderabad, India, 6-12 September 2009; Taniguchi, M., Dausman, A., Howard, K., Polemio, M., Lakshmana, T., Eds.; IAHS Press: Wallingford, UK, 2009.

8. Foster, S.; Hirata, R. Groundwater use for urban development: Enhancing benefits and reducing risks. Water Front 2011, 21-29.

9. Foster, S.; Bousquet, A.; Furey, S. Urban groundwater use in Tropical Africa-a key factor in enhancing water security? Water Policy 2018, 20, 982-994. [CrossRef]

10. Resilient Cities and Groundwater. IAH Strategic Overview Series. Available online: https://iah.org/wpcontent/uploads/2015/12/IAH-Resilient-Cities-Groundwater-Dec-2015.pdf (accessed on 1 September 2019).

11. Morris, B.L.; Seddique, A.A.; Ahmed, K.M. 2003 Response of the Dupi Tila Aquifer to intensive pumping in Dhaka-Bangladesh. Hydrogeol. J. 2003, 11, 496-503. [CrossRef]

12. Lyu, H.M.; Sun, W.J.; Shen, S.L.; Arulrajah, A. Flood risk assessment in metro systems of mega-cities using a GIS-based modeling approach. Sci. Total Environ. 2018, 626, 1012-1025. [CrossRef] [PubMed]

13. Lyu, H.M.; Shen, S.L.; Zhan, A.; Yang, J. Risk assessment of mega-city infrastructure related to land subsidence using improved trapezoidal FAHP. Sci. Total Environ. 2019, 135310. [CrossRef] [PubMed]

14. Foster, S.; Hirata, R.; D'Elia, M.; Paris, M. Groundwater Quality Protection-A Guide for Water-Service Companies, Municipal Authorities and Environment Agencies; GW-MATe Publication; World Bank: Washington, DC, USA, 2007. Available online: www.un-igrac.org (accessed on 1 September 2019).

15. Sun, R.; Jin, M.; Giordano, M.; Villholth, K. Urban and rural groundwater use in Zhengzhou-China: Challenges in joint management. Hydrogeol. J. 2009, 17, 1495-1506. [CrossRef]

16. Foster, S.S.D.; Chilton, P.J. Downstream of downtown-urban wastewater as groundwater recharge. Hydrogeol. J. 2004, 12, 115-120. [CrossRef]

17. Gronwall, J.T.; Mulenga, M.; McGranahan, G. Groundwater and Poor Urban Dwellers-A Review with Case Studies of Bangalore and Lusaka; IIED Human Settlements Working Paper 25; International Institute for Environment and Development: London, UK, 2010.

18. Vairavamoorthy, K.; Tsegaye, S.; Eckart, J. Urban water management in cities of the future: Emerging areas in developing countries. Water Front 2011, 42-48. 